\title{
Research on Energy Saving of Platform Lighting in An Underground Transport Hub in Tianjin
}

\author{
Yangyang $\mathrm{Wu}^{1, \mathrm{a}}$, Wei $\mathrm{Li}^{1, \mathrm{~b}}$ \\ ${ }^{1}$ Institute of green architecture technology and Application, Tianjin Chengjian University, Jinjing \\ Street, Tianjin, China
}

a772871847@qq.com, ${ }^{\mathrm{b}}$ liweiliwei75@126.com

\begin{abstract}
Keywords: underground transport hub, numerical simulation, lighting, energy saving
Abstract. In this paper, the numerical simulation method is used to optimize the lighting simulation and energy-saving evaluation of a subway station in Tianjin. The simulation results show that after the optimization of the lighting design, the mean value of Illumination on the spring and autumn equinoxes of the platform increases from $93.781 \mathrm{x}$ to $108.331 \mathrm{x}$, increasing by $15.56 \%$; the average value of the summer solstice illumination increases from $110.971 x$ to $131.651 x$, increasing by $18.64 \%$; The average value of winter solstice illumination increases from $62.821 \mathrm{x}$ to $74.291 \mathrm{x}$, increasing by $18.26 \%$. The energy saving amount is $28.8 \mathrm{KWh} /$ day and the energy saving rate is $14.22 \%$. The energy saving rate is $37.48 \mathrm{KWh} /$ day in the summer solstice and the energy saving rate is $19.42 \%$. On the winter solstice, it saves energy $18.09 \mathrm{KWh} /$ day and the energy saving rate is $7.12 \%$.
\end{abstract}

\section{Introduction}

The use of natural light is an important aspect of sustainable development of buildings. Scientific and rational use of natural daylighting can save lighting electricity, reduce building energy consumption, indirectly reduce harmful gas emissions and natural resource consumption, playing a very important role in creating a healthy and comfortable environment[1-5]. The actual survey finds that the basic illumination of underground transport hub mainly uses artificial lighting, seldom uses natural lighting and natural lighting combined with artificial lighting. It also finds that many underground transport hubs only use artificial lighting instead of making full of their lighting conditions,, which wastes energy and lowers the comfort level[6-9].

In this paper, the Radiance IES module in IES $\langle\mathrm{VE}\rangle$ is used to optimize the lighting simulation and energy-saving evaluation of the basement of the second floor of an underground transport hub in Tianjin, and to put forward practical lighting design optimization strategies, It will provide reference for the research on lighting energy saving evaluation of underground transport hub.

\section{Research object}

The research object of this paper is a large-scale underground transport hub extending from Beijing-Tianjin inter-city extension to Tianjin Binhai New Area. The hub is designed to have three underground floors. The maximum underground depth is about 33 meters, and he total construction area is about 260,000 square meters. The ground is designed to have a shell-shaped dome structure, The main function of the ground floor is entrance hall, through which passengers can go down to the waiting area in the first floor underground. A big oval hole is dug into the floor under the dome. On the first underground floor under the hole, there are the waiting room of the inter-city train station, ticket lobby, entrance and exit hall and office of management, and facility rooms, etc. On the second underground floor, there are an inter-city railway station platform and a metro platform with two lines. The inter-city railway station has three platforms and six lines. The third underground floor is the platform floor of metro line.[10,11].

This paper studies the natural lighting energy saving of the second underground floor of platform of the underground transport hub. 


\section{The Establishment of the Calculation Model and the setting of relevant parameters}

According to the data and information collected in the research, a model is established (Figure 1) based on the research content and related standards. The model is 220 meters long and 60.5 meters wide. The height of the ground floor is $0 \mathrm{~m}$, the height of the first underground floor is $11 \mathrm{~m}$, and the height of the second underground floor is $19.8 \mathrm{~m}$.

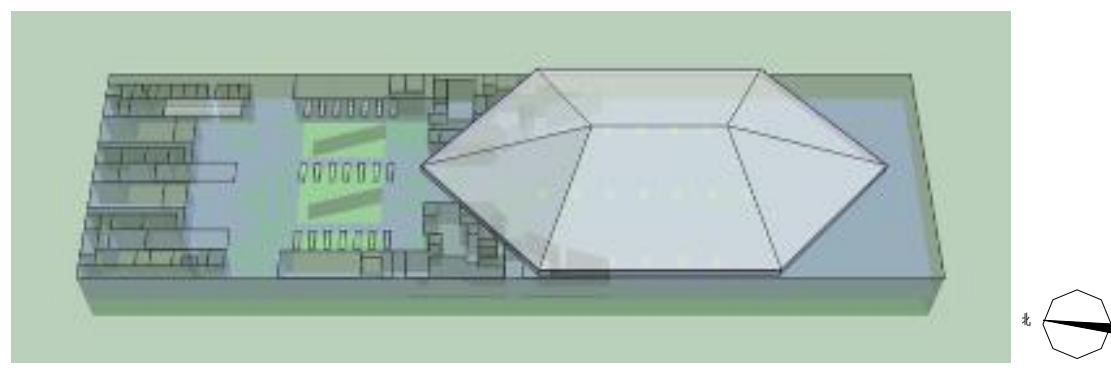

Figure 1 Numerical simulation model

The waiting room is designed to have roof openings (Figure 2) with an area of 3600 square meters. Under the condition of ensuring the same area and integrated transmittance, the part under the "shell" dome structure is simplified to facilitate the numerical simulation. There are a total of 15 rhombus lighting openings (Figure 3). Each lighting area is 6.65 square meters and the total opening area is about 100 square meters, accounting for $0.68 \%$ of the total public area of the platform.

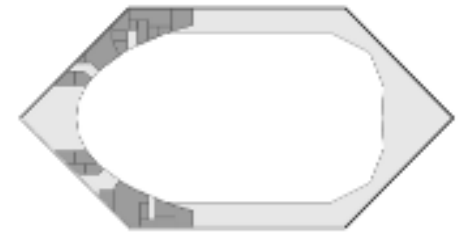

Figure 2 Waiting room's roof openings

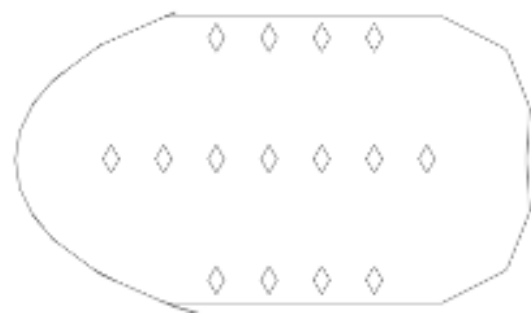

Figure 3 Waiting room plate holes

The underground transport hub is located in Tianjin (latitude $39^{\circ} 06^{\prime}$, longitude $117^{\circ} 10^{\prime}$ east) and belongs to the category III photothermal climate zone. Located at the warm temperate zone, Tianjin has a semi-humid continental monsoon climate, with four distinct seasons. The solar altitude at noon on winter solstice is $27^{\circ} 54$ ', and the one on summer solstice is $73^{\circ} 51^{\prime}$. The annual midday solar altitude changes within this range. Tianjin's annual average diffuse illuminance is $11.7 \mathrm{klx}$, the annual sunshine hours are between 2500 to 2900 hours, with long sunshine duration., Therefore, Tianjin has good natural conditions to make full use of natural light.

As the vernal equinox and autumn equinox sky and sun incident conditions are basically the same, in order to simplify the workload, this paper doesn't imulates the equinox daylighting situation, and just uses he autumn equinox simulation result to represent the spring and autumn equinox daylighting situation. In the Radiance IES module, the lighting simulation dates are set as June 21 (summer solstice), September 23 (autumn equinox) and December 22 (winter solstice) respectively. The simulation time is set as 8:00, 9:00,10:00,11:00,12:00,13:00,14:00,15:00,16:00,17: 00, and the research scene is set to be sunny sky.

The reflectance of the inner surface of the platform is respectively set as follows: 0.70 for the inner surface wall surface, 0.20 for the ground surface and 0.90 for the ceiling surface. Taking into account the light blocking by the people inside the station hall and the glass, the researchers set the glass roof transmittance of 0.50 . 


\section{Simulation results and energy-saving evaluation and analysis}

\section{Lighting optimization simulation}

The original program: platform floor uses rhombus lighting openings each one covering 6.65 square meters, with a total of 15 , the total opening area covering about 100 square meters, accounting for $0.68 \%$ of the area of the public area of the platform.

Optimization program: Whereas the total area of the light(daylight) openings unchanged, the shape and number of light openings are. In the positions of the original daylight openings, rhombus light openings are replaced with square ones.Each opening has an area of 4 square meters, all together 25 ones, with a total area of 100 square meters.

The original scheme and optimization scheme of the light distribution diagram are shown in Figure 4.

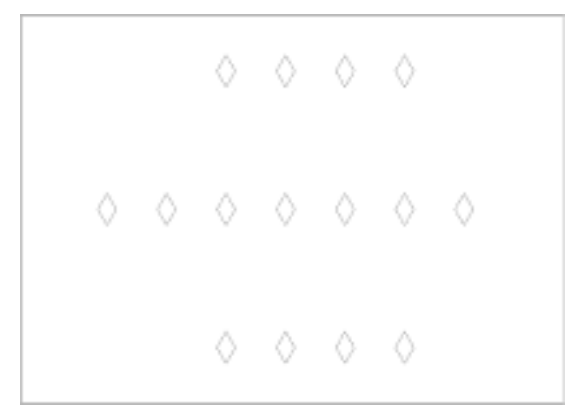

The original program

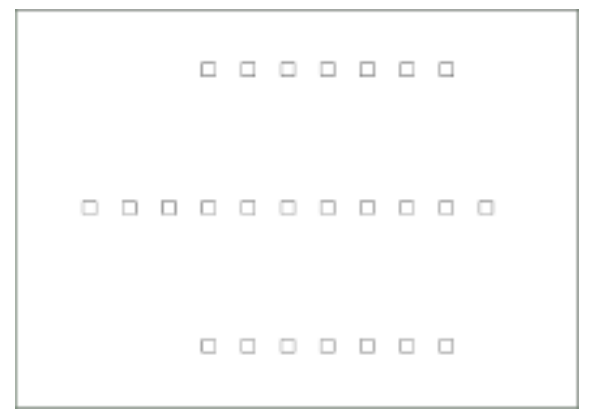

Optimization program

Figure 4 daylight opening distribution map

By lighting numerical simulation, the average illuminance of the platform floor (Table 1) is obtained.

Table 1 The average illuminance of the platform floor

\begin{tabular}{|c|c|c|c|c|c|}
\hline \multicolumn{3}{|c|}{ The original program } & \multicolumn{3}{|c|}{ The optimization program } \\
\hline Season & Moment & $\begin{array}{c}\text { The } \\
\text { average } \\
\text { illuminance } \\
(1 \mathrm{x})\end{array}$ & Season & Moment & $\begin{array}{c}\text { The } \\
\text { average } \\
\text { illuminance } \\
(1 \mathrm{x})\end{array}$ \\
\hline \multirow[t]{11}{*}{ Equinoxes } & $8: 00$ & 73.84 & \multirow[t]{11}{*}{ Equinoxes } & $8: 00$ & 87.41 \\
\hline & 9:00 & 92.74 & & 9:00 & 109.92 \\
\hline & $10: 00$ & 106.02 & & $10: 00$ & 97.38 \\
\hline & $11: 00$ & 111.44 & & $11: 00$ & 132.30 \\
\hline & $12: 00$ & 113.90 & & $12: 00$ & 135.18 \\
\hline & 13:00 & 112.34 & & 13:00 & 133.20 \\
\hline & $14: 00$ & 105.96 & & $14: 00$ & 125.38 \\
\hline & $15: 00$ & 94.70 & & $15: 00$ & 111.78 \\
\hline & $16: 00$ & 75.68 & & $16: 00$ & 89.29 \\
\hline & $17: 00$ & 52.10 & & $17: 00$ & 61.49 \\
\hline & $\begin{array}{l}\text { Average } \\
\text { value }\end{array}$ & 93.87 & & $\begin{array}{l}\text { Average } \\
\text { value }\end{array}$ & 108.33 \\
\hline \multirow{7}{*}{$\begin{array}{l}\text { Summer } \\
\text { Solstice }\end{array}$} & 8:00 & 95.03 & \multirow{7}{*}{$\begin{array}{l}\text { Summer } \\
\text { Solstice }\end{array}$} & $8: 00$ & 112.66 \\
\hline & 9:00 & 107.40 & & 9:00 & 127.57 \\
\hline & $10: 00$ & 113.49 & & $10: 00$ & 134.90 \\
\hline & $11: 00$ & 121.47 & & $11: 00$ & 144.44 \\
\hline & $12: 00$ & 133.57 & & $12: 00$ & 158.80 \\
\hline & 13:00 & 127.00 & & $13: 00$ & 150.89 \\
\hline & $14: 00$ & 116.25 & & $14: 00$ & 137.95 \\
\hline
\end{tabular}




\begin{tabular}{|c|c|c|c|c|c|}
\hline & $15: 00$ & 109.93 & & $15: 00$ & 130.20 \\
\hline & $16: 00$ & 100.66 & & $16: 00$ & 118.89 \\
\hline & $17: 00$ & 84.89 & & $17: 00$ & 100.15 \\
\hline & $\begin{array}{l}\text { Average } \\
\text { value }\end{array}$ & 110.97 & & $\begin{array}{l}\text { Average } \\
\text { value }\end{array}$ & 131.65 \\
\hline \multirow{11}{*}{$\begin{array}{l}\text { Winter } \\
\text { solstice }\end{array}$} & $8: 00$ & 37.14 & \multirow{11}{*}{$\begin{array}{l}\text { Winter } \\
\text { solstice }\end{array}$} & 8:00 & 43.95 \\
\hline & $9: 00$ & 56.75 & & 9:00 & 67.16 \\
\hline & $10: 00$ & 73.27 & & $10: 00$ & 86.76 \\
\hline & 11:00 & 83.63 & & 11:00 & 99.06 \\
\hline & $12: 00$ & 87.69 & & $12: 00$ & 103.84 \\
\hline & 13:00 & 85.45 & & 13:00 & 101.07 \\
\hline & $14: 00$ & 76.37 & & $14: 00$ & 90.16 \\
\hline & 15:00 & 61.88 & & $15: 00$ & 73.00 \\
\hline & $16: 00$ & 42.81 & & $16: 00$ & 50.53 \\
\hline & $17: 00$ & 23.20 & & $17: 00$ & 27.38 \\
\hline & $\begin{array}{l}\text { Average } \\
\text { value }\end{array}$ & 62.82 & & $\begin{array}{l}\text { Average } \\
\text { value }\end{array}$ & 74.29 \\
\hline
\end{tabular}

The following are illuminance distribution cloud maps (Figure 5,6) of the original program and optimization program chosen at three points of time.
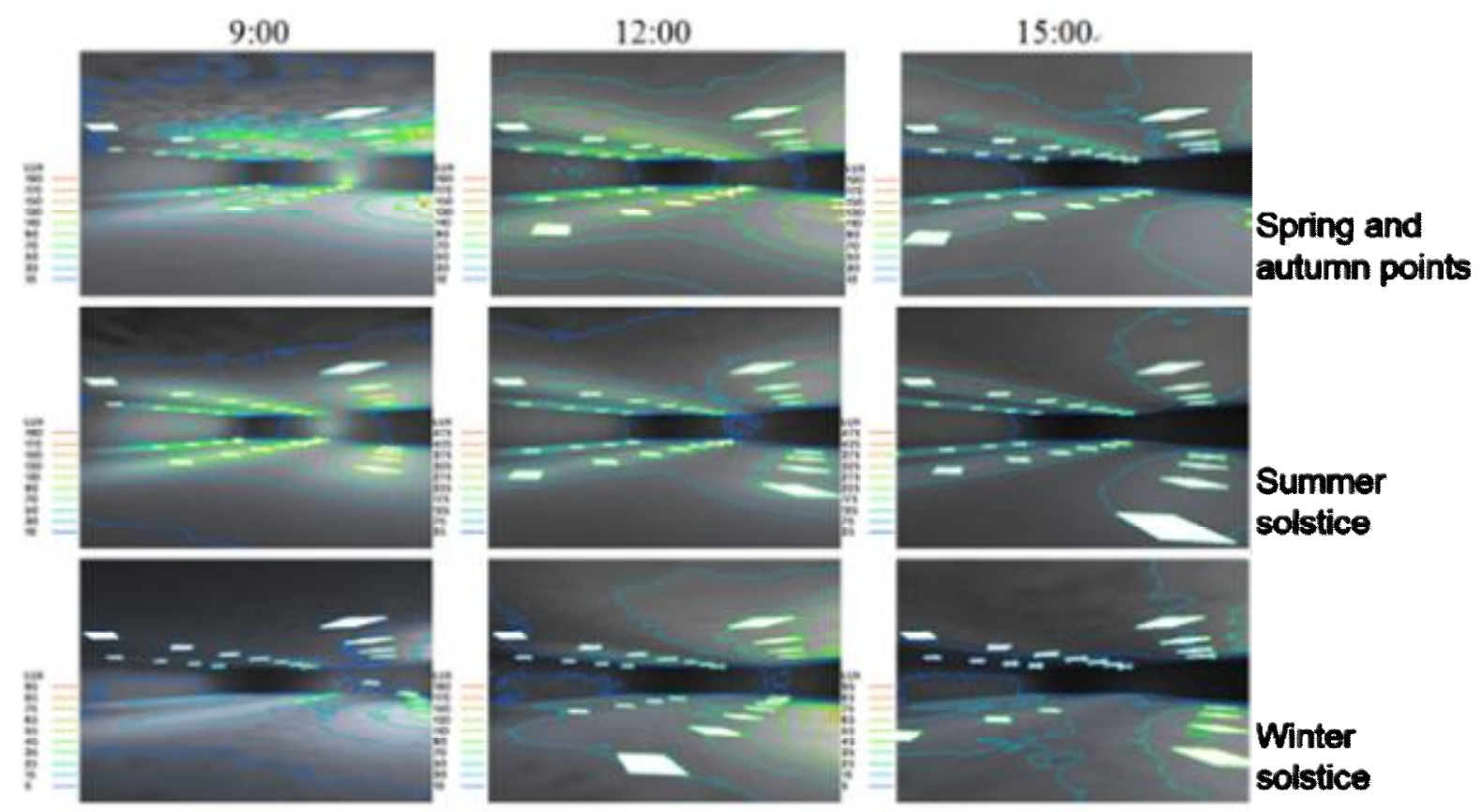

Figure 5 The illuminance distribution cloud map of the original plan 


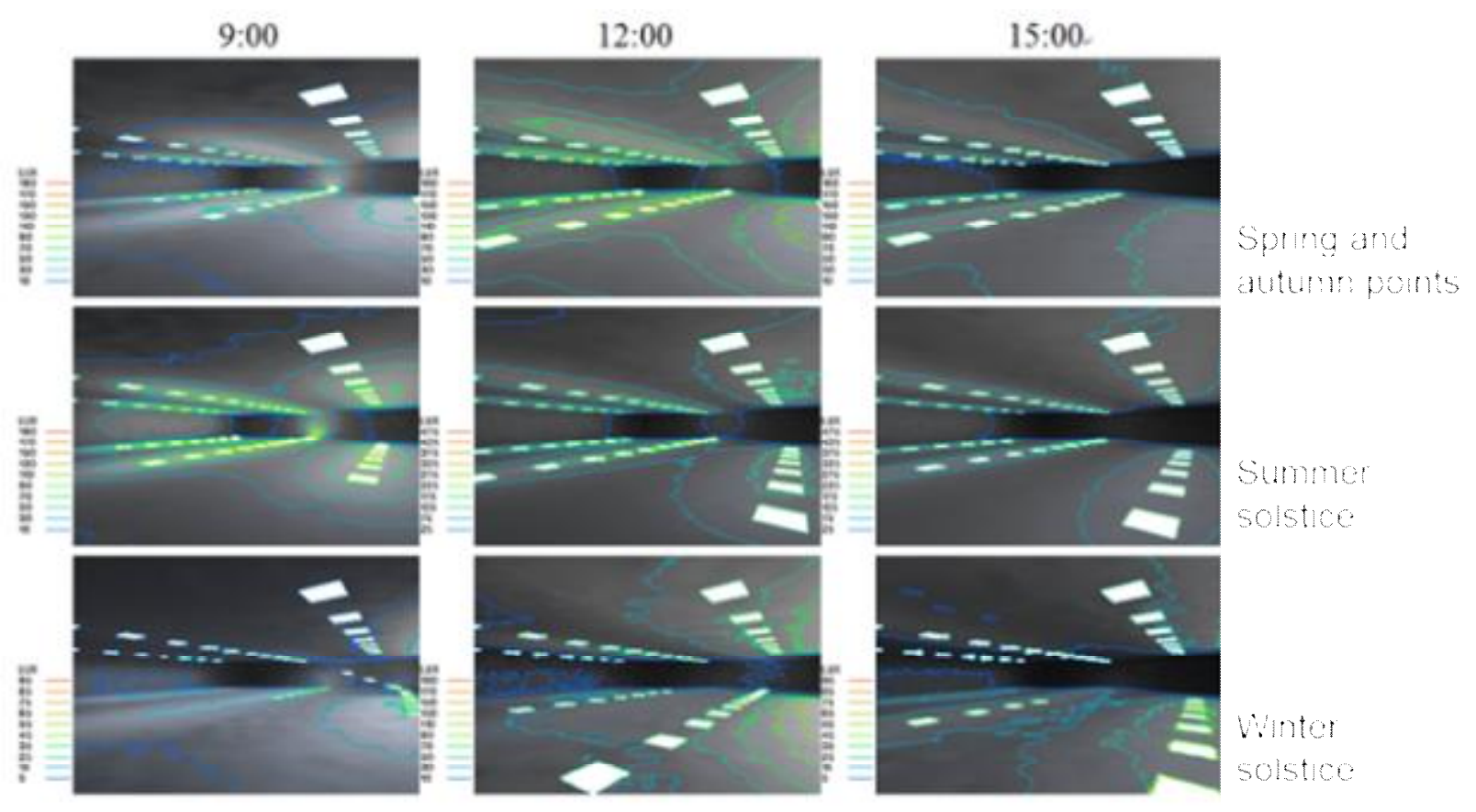

Figure 6 The illuminance distribution cloud map of the Optimal plan

The simulation results show that in the sunny scene, the average value of spring and autumn illumination intensity of the optimized scheme increased from 93.781x in the original scheme to 108.331x and increased by $15.56 \%$; the average value of summer solstice illumination increased from $110.971 x$ to $131.651 x$, an increase of $18.64 \%$; The average value of the winter solstice illumination increased from $62.821 \mathrm{x}$ to $74.291 \mathrm{x}$, an increase of $18.26 \%$.

\section{Energy-saving evaluation and analysis}

In this paper, the energy-saving evaluation and analysis method is as follows: According to the lighting simulation results of lighting energy-saving analysis, the researchers select the target value of lighting power density with the corresponding illuminance as the calculation standard.As the transportation hub project is an underground project, trains run all day, therefore, the lighting time is 24 hours. The natural lighting is calculated from 8:00 to 17:00 (9 hours). By using the proportion and size of the area calculated by the software that exceeds the corresponding illuminance value, the saved lighting energy consumption is analyzed.

According to "Urban Rail Transit Lighting" (GB/T 16275-2008) standards, the corresponding level of underground station platform illumination should reach 1501x. The illumination values were set to be 1501x, 1001x and 501x.In the lighting numerical simulation results, The proportion of the area that exceeds the corresponding illumination value to the whole area will be checked.

(1) Energy consumption calculation of platform floor lighting without light entrance

Illumination power density values of $9 \mathrm{~W} / \mathrm{m}^{2}$ and $1502.5 \mathrm{~m}^{2}$ were obtained when the site illumination level reached 150lx. In the absence of natural light without light exposure, the formula for lighting energy consumption can be obtained as follows:

$$
E=P \cdot t \cdot A
$$

In the formula,

E - Lighting energy consumption in one day;

$\mathrm{P}$ - Lighting power density;

$\mathrm{t}$ - The number of working hours a day;

$\mathrm{A}$ - Area of region. 
Therefore, when there is no light at the platform without natural light exposure, the day's lighting energy consumption is

$$
\begin{aligned}
\mathrm{E} & =\mathrm{P} \cdot \mathrm{t} \cdot \mathrm{A} \\
& =9 \mathrm{~W} / \mathrm{m}^{2} \times 24 \mathrm{~h} \times 5142.5 \mathrm{~m}^{2} \times 1 / 1000 \\
& =1110.78 \mathrm{KWh}
\end{aligned}
$$

There are 365 days in a year. That means the working hours are 8760 hours, the annual energy consumption of lighting is $405434.7 \mathrm{KWh}$.

(2) The platform floor lighting energy consumption calculation of the original program

According to the simulation results of daylighting, we can see that the ratio of the areas with spring illumination over $150 \mathrm{~lx}$ is $21.61 \%$, which is 1111.29 square meters; the area over $100 \mathrm{~lx}$ accounts for $41.10 \%$ or 2113.57 square meters; more than $50 \mathrm{~lx}$ area accounts for $59.55 \%$ of the area, which is 3062.36 square meters.

The proportion of areas with more than 150lx summer solstice was $29.80 \%$ or $1532.47 \mathrm{~m}^{2}$; the area over $1001 \mathrm{x}$ accounted for $46.13 \%$ or $2372.24 \mathrm{~m} 2$; and the area over $501 \mathrm{x}$ accounted for $60.17 \%$ which is $3094.24 \mathrm{~m}^{2}$.

Winter solstice illumination over $1501 \mathrm{x}$ area accounts for $7.85 \%$, which is 403.69 square meters; more than 1001x of the area account $\mathrm{s}$ for $22.53 \%$, which is 1158.61 square meters; more than 50lx of the area accounts for $49.74 \%$, which is 2557.88 square meters.

It can be seen in each area of illumination intensity distribution and size of the area, shown in Table

\begin{tabular}{|c|c|c|c|}
\hline Season & $\begin{array}{l}\text { Illumination value } \\
\qquad(1 \mathrm{x})\end{array}$ & $\begin{array}{l}\text { The proportion of } \\
\text { area }(\%)\end{array}$ & Area $\left(\mathrm{m}^{2}\right)$ \\
\hline \multirow[t]{4}{*}{ Equinoxes } & Over 150 & 21.61 & 1111.29 \\
\hline & $100 \sim 150$ & 19.49 & 1002.28 \\
\hline & $50 \sim 100$ & 18.45 & 948.79 \\
\hline & $0 \sim 50$ & 40.45 & 2080.14 \\
\hline \multirow{4}{*}{$\begin{array}{l}\text { Summer } \\
\text { Solstice }\end{array}$} & Over 150 & 29.80 & 1532.47 \\
\hline & $100 \sim 150$ & 16.33 & 839.87 \\
\hline & $50 \sim 100$ & 14.04 & 722.00 \\
\hline & $0 \sim 50$ & 39.83 & 2048.26 \\
\hline \multirow{4}{*}{$\begin{array}{l}\text { Winter } \\
\text { Solstice }\end{array}$} & Over 150 & 7.85 & 403.69 \\
\hline & $100 \sim 150$ & 14.95 & 754.92 \\
\hline & $50 \sim 100$ & 27.21 & 1399.27 \\
\hline & $0 \sim 50$ & 50.26 & 2584.62 \\
\hline
\end{tabular}
2。

Table 2 The illuminance value area distribution and size of the original program

Based on the provisions of "Design Standard for Building Lighting Design" (GB50033-2013) and "Urban Rail Transit Lighting" (GB / T 16275-2008), this paper uses a uniform standard in calculating energy saving rate and energy saving rate, which is, when the illumination value exceeds $1501 x$, it meets the lighting design standards of underground space and can replace the artificial lighting. When the illuminance value is in the range of 100-150 lx, the artificial lighting of $1 \mathrm{~W} / \mathrm{m}^{2}$ is added. When the The illumination value is in the range of $50-1001 \mathrm{x}$, the artificial lighting of $3 \mathrm{~W} / \mathrm{m}^{2}$ is added.Artificial lighting Illumination value in the 0-501x range, artificial lighting is used. The lighting power density value is $9 \mathrm{~W} / \mathrm{m}^{2}$, natural daylight hours are from 8:00 to 17:00, a total of 9 hours. The lighting energy consumption is calculated according to formula (4-2). 


$$
E_{\mathrm{s}}=P_{1} \cdot t_{1} \cdot A_{1}+\cdots+P_{n} \cdot t_{n} \cdot A_{n}
$$

Through the calculation, we can obtain the lighting energy consumption of the platform floor under the design of the original design daylight opening 。

Spring and autumn equinoxes:

$\mathrm{E}$ 总 $=\left(1 \mathrm{~W} / \mathrm{m}^{2} \times 9 \mathrm{~h} \times 1002.28 \mathrm{~m}^{2}+3 \mathrm{~W} / \mathrm{m}^{2} \times 9 \mathrm{~h} \times 948.79 \mathrm{~m}^{2}+9 \mathrm{~W} / \mathrm{m}^{2} \times 9 \mathrm{~h} \times 2080.14 \mathrm{~m}^{2}+9\right.$ $\left.\mathrm{W} / \mathrm{m}^{2} \times 15 \mathrm{~h} \times 5142.5 \mathrm{~m}^{2}\right) \times 1 / 1000$

$$
=897.37 \mathrm{KWh}
$$

Summer solstice:

$\mathrm{E}$ 总 $=\left(1 \mathrm{~W} / \mathrm{m}^{2} \times 9 \mathrm{~h} \times 839.87 \mathrm{~m}^{2}+3 \mathrm{~W} / \mathrm{m}^{2} \times 9 \mathrm{~h} \times 722.00 \mathrm{~m}^{2}+9 \mathrm{~W} / \mathrm{m}^{2} \times 9 \mathrm{~h} \times 2048.26 \mathrm{~m}^{2}+9\right.$ $\left.\mathrm{W} / \mathrm{m}^{2} \times 15 \mathrm{~h} \times 5142.5 \mathrm{~m}^{2}\right) \times 1 / 1000$ $=887.20 \mathrm{KWh}$

Winter solstice:

$\mathrm{E}$ 总 $=\left(1 \mathrm{~W} / \mathrm{m}^{2} \times 9 \mathrm{~h} \times 754.92 \mathrm{~m}^{2}+3 \mathrm{~W} / \mathrm{m}^{2} \times 9 \mathrm{~h} \times 1399.27 \mathrm{~m}^{2}+9 \mathrm{~W} / \mathrm{m}^{2} \times 9 \mathrm{~h} \times 2584.62 \mathrm{~m}^{2}+9\right.$ $\left.\mathrm{W} / \mathrm{m}^{2} \times 15 \mathrm{~h} \times 5142.5 \mathrm{~m}^{2}\right) \times 1 / 1000$

$$
=948.17 \mathrm{KWh}
$$

Compared with the case of using artificial lighting (lighting energy consumption is $1110.78 \mathrm{KWh}$ ), the original scheme saves $213.41 \mathrm{KWh} /$ day in energy saving and $19.21 \%$ in energy saving;in the summer solstice it saves $223.58 \mathrm{KWh} /$ day and the energy-saving rate is $20.13 \%$; in the $\mathrm{w}$ inter solstice the energy that it saves is $162.61 \mathrm{KWh} /$ day, and the energy saving rate is $14.64 \%$.

(3)Optimization scheme Lighting calculation of platform Lighting energy consumption calculation under the optimization scheme

According to the results of numerical simulation of lighting, we can see that the proportion of the areas where the spring and autumn illumination exceeded $1501 \mathrm{x}$ was $19.87 \%$, that is $1021.81 \mathrm{~m}^{2}$; the area with the area over $1001 \mathrm{x}$ was $43.59 \%$, that is $2241.62 \mathrm{~m}^{2}$; More than $501 \mathrm{x}$ area accounted for $69.41 \%$ of the area, that is 3569.41 square meters 。

Summer solstice illumination area of more than 1501x accounted for $30.92 \%$ of the area, which is 1590.06 square meters; more than 1001x area accounted for $52.61 \%$ of the area, which is 2705.47 square meters; more than 501x area accounted for $71.32 \%$ of the area, which is 3667.63 square meters.

Winter solstice illumination over $1501 \mathrm{x}$ area accounted for $6.65 \%$ of the area, or 341.98 square meters; more than $1001 \mathrm{x}$ area accounted for $21.88 \%$ of the area, that is 1125.18 square meters; over $501 x$ area accounted for $56.67 \%$ of the area, that is 2914.25 square meters.

Table 3 shows the area distribution and the area size of each luminance value interval.

Table 3 Optimization program illuminance value area distribution and size

\begin{tabular}{|c|c|c|c|}
\hline \multirow{2}{*}{ Season } & $\begin{array}{c}\text { Illumination value } \\
(1 \mathrm{x})\end{array}$ & $\begin{array}{c}\text { The proportion of } \\
\text { area }(\%)\end{array}$ & Area $\left(\mathrm{m}^{2}\right)$ \\
\hline \multirow{3}{*}{ Equinoxes } & Over 150 & 19.87 & 1021.81 \\
\cline { 2 - 4 } & $100 \sim 150$ & 23.72 & 1219.81 \\
\cline { 2 - 4 } & $50 \sim 100$ & 25.82 & 1327.79 \\
\cline { 2 - 4 } & $0 \sim 50$ & 30.59 & 1573.09 \\
\hline \multirow{5}{*}{ Summer solstice } & Over 150 & 30.92 & 1590.06 \\
\cline { 2 - 4 } & $100 \sim 150$ & 21.69 & 1115.41 \\
\cline { 2 - 4 } & $50 \sim 100$ & 18.71 & 1474.87 \\
\cline { 2 - 4 } & $0 \sim 50$ & 28.68 & 341.98 \\
\hline \multirow{4}{*}{ Winter solstice } & Over 150 & 6.65 & 783.20 \\
\cline { 2 - 4 } & $100 \sim 150$ & 15.23 & 1789.07 \\
\cline { 2 - 4 } & $50 \sim 100$ & 34.79 & 2228.25 \\
\cline { 2 - 4 } & $0 \sim 50$ & 43.33 & \\
\hline
\end{tabular}


By the formula (4-2) can be calculated as the optimal design daylight opening design day lighting energy consumption.

Spring and autumn equinoxes:

$\mathrm{E}_{\mathrm{s}}=\quad\left(1 \mathrm{~W} / \mathrm{m}^{2} \times 9 \mathrm{~h} \times 1219.81 \mathrm{~m}^{2}+3 \mathrm{~W} / \mathrm{m}^{2} \times 9 \mathrm{~h} \times 1327.79 \mathrm{~m}^{2}+9 \mathrm{~W} / \mathrm{m}^{2} \times 9 \mathrm{~h} \times 1573.09 \mathrm{~m}^{2}+9\right.$

$\left.\mathrm{W} / \mathrm{m}^{2} \times 15 \mathrm{~h} \times 5142.5 \mathrm{~m}^{2}\right) \times 1 / 1000$

$=868.49 \mathrm{KWh}$

Summer solstice:

$\mathrm{E}_{\mathrm{s}}=\quad\left(1 \mathrm{~W} / \mathrm{m}^{2} \times 9 \mathrm{~h} \times 1115.41 \mathrm{~m}^{2}+3 \mathrm{~W} / \mathrm{m}^{2} \times 9 \mathrm{~h} \times 962.16 \mathrm{~m}^{2}+9 \mathrm{~W} / \mathrm{m}^{2} \times 9 \mathrm{~h} \times 1474.87 \mathrm{~m}^{2}+9\right.$

$\left.\mathrm{W} / \mathrm{m}^{2} \times 15 \mathrm{~h} \times 5142.5 \mathrm{~m}^{2}\right) \times 1 / 1000$

$=849.72 \mathrm{KWh}$

Winter solstice:

$\mathrm{E}$ 总 $=\left(1 \mathrm{~W} / \mathrm{m}^{2} \times 9 \mathrm{~h} \times 783.2 \mathrm{~m}^{2}+3 \mathrm{~W} / \mathrm{m}^{2} \times 9 \mathrm{~h} \times 1789.07 \mathrm{~m}^{2}+9 \mathrm{~W} / \mathrm{m}^{2} \times 9 \mathrm{~h} \times 2228.25 \mathrm{~m}^{2}+9\right.$

$\left.\mathrm{W} / \mathrm{m}^{2} \times 15 \mathrm{~h} \times 5142.5 \mathrm{~m}^{2}\right) \times 1 / 1000$

$=930.08 \mathrm{KWh}$

Compared with the case of using artificial lighting (energy consumption of lighting is $1110.78 \mathrm{KWh}$ ), the optimal scheme is $242.29 \mathrm{KWh} /$ day in energy saving and $21.81 \%$ in energy saving; the summer solstice energy saving is $261.06 \mathrm{KWh} /$ day and the energy saving rate is $23.50 \%$; in winter solstice, the energy it saves is $180.70 \mathrm{KWh} /$ day, with an energy-saving rate of $16.27 \%$.

(4) Optimization program energy analysis

In the following, a comparative analysis will be carried out on the energy saving amount and energy saving rate between the original program and the optimization program under the circumstance of natural daylight hours (8:00 to 17:00).

According to the formula (4-2), we can calculate the lighting energy consumption of the original scheme and the optimized scheme under natural lighting conditions respectively. The results are shown in Table 4.

Table 4 Lighting energy consumption under natural lighting conditions

\begin{tabular}{|c|c|c|}
\hline \multirow{2}{*}{ Season } & \multicolumn{2}{|c|}{ Lighting energy consumption (KWh) } \\
\cline { 2 - 3 } & The original program & The optimization program \\
\hline $\begin{array}{c}\text { Spring and autumn } \\
\text { equinoxes }\end{array}$ & 203.13 & 174.25 \\
\hline Summer solstice & 192.96 & 155.48 \\
\hline Winter solstice & 253.93 & 235.84 \\
\hline
\end{tabular}

Through the calculation we can see that in the premise of the natural lighting time (8:00 to 17:00) without considering the night artificial lighting, the optimized scheme is $28.8 \mathrm{KWh} /$ day more energy saving than the original scheme, and energy saving rate is $14.22 \%$; the energy saving rate is 37.48 $\mathrm{KWh} /$ day in the summer solstice, and energy saving rate is $19.42 \%$; the energy saving rate is 18.09 $\mathrm{KWh} /$ day in the solstice, and energy saving rate is $7.12 \%$.

After the above analysis, we can see the energy-saving optimization programs and energy-saving rate and the specific values in Table 5. 
Table 5 The summary sheet of energy saving amount and rate under optimization program

\begin{tabular}{|c|c|c|c|c|}
\hline Season & \multicolumn{2}{|c|}{ Compared to the original plan } & \multicolumn{2}{c|}{ Compared with no light port situation } \\
\hline & $\begin{array}{c}\text { Energy saving } \\
(\text { KWh/Day })\end{array}$ & $\begin{array}{c}\text { Energy } \\
\text { saving rate }(\%)\end{array}$ & $\begin{array}{c}\text { Energy saving } \\
\text { KWh/Day })\end{array}$ & $\begin{array}{c}\text { Energy } \\
\text { saving rate }(\%)\end{array}$ \\
\hline $\begin{array}{c}\text { Spring and } \\
\text { autumn } \\
\text { equinoxes }\end{array}$ & 28.8 & 14.22 & 242.29 & 21.81 \\
\hline $\begin{array}{c}\text { Summer } \\
\text { solstice }\end{array}$ & 37.48 & 19.42 & 261.06 & 16.27 \\
\hline $\begin{array}{c}\text { Winter } \\
\text { solstice }\end{array}$ & 18.09 & 7.12 & 180.70 & \\
\hline
\end{tabular}

\section{Conclusion}

The shape, size, quantity and location of the daylight openings have a great influence on the natural lighting of the underground traffic hub. Taking the underground transportation hub studied in this paper as an example, the total area of the daylight openings in the platform floor remains unchanged, the area of the single daylight openings is reduced and the number of the daylight openings is increased. The 15 rhombus openings in the original proposal are optimized for 25 square daylight openings, In the sunny day, the average value of spring and autumn equinoxes illumination increased from 93.781x in the original program to $108.331 x$, with an increase of $15.56 \%$; the average value of summer solstice illumination increased from 110.971x to $131.651 \mathrm{x}$, an increase of $18.64 \%$; the average of the winter solstice illumination increased from $62.821 \mathrm{x}$ to $74.291 \mathrm{x}$, an increase of $18.26 \%$.

Through energy-saving evaluation analysis and research, we can find that rational natural daylighting design will reduce the energy consumption of underground transport hub, with huge potential of energy saving. In the premise of the natural lighting time (8:00 to 17:00) without considering the artificial lighting at night, compared with the original program, the optimization program of the underground transport hub saves energy $28.8 \mathrm{KWh} /$ day at the saving rate of $14.22 \%$ on the spring and autumn equinoxes; it saves energy $37.48 \mathrm{KWh} /$ day at the rate of $19.42 \%$ on the summer solstice; it saves energy $18.09 \mathrm{KWh} /$ day at the rate of $7.12 \%$ on the winter solstice. The energy saving amount and rate of the project reaches a good level.

\section{Acknowledgements}

This work was supported by Tianjin Science and Technology Support Project (Grant Numbers 15ZCZDSF00080); Tianjin Science and Technology Support Project (Grant Numbers 16PTGCCX00060);National Key R\&D Program of China （Grant No.2016YFC0700201 ).

\section{References:}

[1] Danny, Joseph. An investigation of daylighting performance and energy saving in a daylit corridor[J]. Energy and Buildings,2003(35):365-373.

[2] G·Z Brown, Mark Dekai, solar radiation, wind, natural light [M]. Chang Zhigang, translated. Beijing: China Building Industry Press,2008.

[3] Wang Hongwei, Coaster, Dynamic natural lighting construction principle and application: The basic principle-Design System - Project Case [M]. translated. Beijing: China Electric Power Press, 2007.

[4] Guo Baozhen. Natural lighting control strategy and energy saving analysis [D] .Shandong University, 2008.

[5] Du Fang, Li Yong, Wu Feng. Energy-saving lighting design of underground buildings [J] Building energy efficiency, 2011 (1): 68-70. 
[6] Wu Wei. Roof of the skylight natural lighting technology design [D]. Southeast University, 2008.

[7] Zhang Bin. The technique research of light environment artistic expression in Subway station building space [D]. Xi'an University of Architecture and Technology, 2012.

[8] Li Xiao Yin. Natural Light and Underground Buildings [D]. Tongji University, 2008.

[9] Luo Yin. Based on the comfort of Chongqing underground street space environment design [D]. Chongqing University,2012.

[10] Xing Jiayong. Yujiapu station underground hub of natural lighting design [J]. Shanxi Architecture, 2012, 38(4): 18-19.

[11]Ma Jin. Tianjin Yujiapu Station traffic hub design ideas [J]. Shanxi Architecture, 2010, 36(12): 46-47. 